\title{
Property Tax on Privatized Roads
}

\author{
Jason Junge* $\quad$ David Levinson $^{\dagger}$
}

*Minnesota Department of Transportation, Jason.Junge@state.mn.us

${ }^{\dagger}$ University of Minnesota, Department of Civil Engineering. dlevinson@umn.edu http : / / nexus .umn.edu 


\begin{abstract}
Roads cover a significant fraction of the land area in many municipalities. The public provision of roads means this land is exempt from the local property tax. Transferring roads from public to private ownership would not only remove maintenance costs from city budgets, but increase potential property tax revenue as well. This paper calculates the value of the land occupied by roads in sample cities and determines the potential revenue increase if they were subject to property tax. Further calculation computes the extent to which the property tax rate could be reduced if the land value of roads were added to the tax base.
\end{abstract}

\title{
1 Introduction
}

Street maintenance is a significant part of many municipal budgets. Especially in older cities, much of the infrastructure is reaching an age where replacement or significant rehabilitation will soon be needed. At the same time, with recent economic conditions the fiscal health of many city governments is in question. Raising property taxes to cover increased street maintenance needs is likely not politically feasible in harder times, and may not be economically feasible given the recent spate of foreclosures. Several alternative instruments are available to finance transportation projects. Generally, these fall into the categories of user fees or value capture. User fees are charged to drivers, most directly in the form of tolls but also as vehicle registration fees. Value capture strategies, such as impact fees and land value taxes, are charged to land owners whose parcels derive value from the accessibility provided by the street network.

A third alternative is to lease or sell the transportation network to a private operator, who would manage and maintain the system and likely charge tolls in some form to cover costs. Such arrangements are becoming more common, especially for large, capital-intensive projects for which it is difficult to obtain construction funding. The most obvious effect, aside from the appearance of tolls on facilities which were previously untolled, is the transfer of the burden of maintaining the system from public agencies to private entities. Another ramification, which is the focus of this paper, is that if ownership of roads were privatized in addition to operation, the owners could be charged property taxes. This would give governments more flexibility to fund other programs, or to reduce property taxes on residents and other businesses.

\section{Private operation of roads-proposals and practice}

Private operation of roads in the United States is rare, but discussion of privatization as a viable option has recently increased. Historically, privately-run toll roads were much more common, but today they are limited to a few corridors and major bridges. The usual motivation for privatizing is that a for-profit business would have a greater incentive than a government agency to minimize costs and operate efficiently. Gómez-Ibáñez et al. (1991) concluded that taxpayers would come out ahead in such an arrangement, with operating companies contributing increased federal and state income taxes and using taxable financing for construction. 


\subsection{Extent of use}

In many countries, freeways are operated by private sector firms under a franchise or concession agreement with the government, which usually retains underlying ownership of the road (Daniels and Trebilcock, 1996; Poole, 1997; Poole Jr and Fixler Jr, 1987). For example, as of 2004 more than 37 percent of motorway length in the EU25 plus Norway and Switzerland was under concession, and 75 percent of that was privately operated (Albalate et al., 2009).

There is limited experience in the United States with contracting operation of existing roads (Engel et al., 2002), which has not been without controversy. Notable examples include the longterm leases of the Indiana Turnpike and Chicago Skyway (Samuel and Poole, 2005). New toll roads built and operated by private firms are much more widespread, and include the Dulles Greenway and Pocahantas Parkway in Virginia, and the Adams Avenue Turnpike in Utah. This experience applies well to toll roads, and variants such as high occupancy/toll (HOT) lanes (Poole et al., 1999) and truck-only tollways (Samuel et al., 2002). California's SR-91 median toll lines were privately built on public right-of-way, and later bought out by a public toll agency. Presently, the MnPASS HOT lanes in Minnesota manage toll collection under a concession to private organizations. A large share of the few new limited-access roads built in the United States have adopted the toll model, and more could follow suit (Fields et al., 2009; Poole and Samuel, 2006; Poole and Sugimoto, 1995; Staley and Moore, 2009).

In these examples, road operation has been commercialized, but the underlying land is retained by a public agency. It is generally more local levels of government, such as cities and counties, that collect property taxes, and higher levels of government are exempt. Existing public highways owned by state transportation departments occupy land in several local jurisdictions, but do not compensate them in the form of property taxes. Similarly, the federal government does not pay tax on the land or buildings occupied by its post offices or court houses. In contrast, if the road facilities and the land beneath them were owned by a private firm (either the operator or another party to whom the operator pays rent), they would be taxable. Transferring land ownership in addition to road operation to a private firm would likely prove even more controversial, but it would provide an additional opportunity for economic efficiency gains. In the same way that charging tolls can improve the allocation of scarce road capacity, charging property tax on roads could improve the allocation of scarce land area within a city.

\subsection{Economic and political feasibility}

Privately-owned local streets do exist, such as those under the control of neighborhood associations, as is common in St. Louis, Missouri, but the economic ramifications of private construction and operation of major highways have received more attention in the literature. In particular, a buildoperate-transfer business model has been considered, in which a private company would build the facility, operate and maintain it for a specified time period, and then turn it over to a public agency (Tsai and Chu, 2003; Yang and Meng, 2000). The results of a model created by Viton (1995) concluded that the prospects of profitable operation of a private intercity route are good, but the money-making opportunities with urban routes are more limited. The model only considered private routes operating in direct competition with public highways, and did not evaluate local roads or private monopolies. However, only recently has the electronic toll-collection technology advanced to the point that charging for minor streets has become a possibility. 
Roth (1996) notes the separation evident in the public sector between funding and responsibility for maintenance and safety. In contrast, a private operator would incur all liabilities in exchange for the ability to retain all profits. This single point of responsibility would likely result in lower costs, better response to needs for improvement and more efficient investments. However, Friedman and Boorstin (1996) note that these improvements would be much more difficult to realize on intra-city networks than on longer-distance routes. The logistics of charging for use are more challenging, and the natural monopoly of a precise route plays a greater role when access to parcels takes precedence over traffic throughput.

Social equity concerns with regard to privatization are also greater lower in the functional hierarchy of roads, as accessibility becomes more important than mobility. Local streets provide benefits above and beyond vehicle throughput and have uses aside from deliberate automotive tripmaking. As these benefits accrue more to parcels than to users, public agency provision is more reasonable for local streets than for major highways, and the incentives for privatization may be less.

Based on historical experience (Levinson, 2002), implementing tolls on existing untolled roads is likely to be politically difficult and unpopular. A factor that may improve acceptability is the presence of competition. This is observed when a toll highway runs parallel to a public road, and users can determine whether they value the likely faster trip on the toll road enough to justify paying the toll. The effect would be even more pronounced if multiple toll facilities were to function as substitutes, competing on price or quality of service. This is one reason that privatizing major highways may be more acceptable and more successful than privatizing an entire network of municipal roads. If all major highways were tolled and all local roads remained free, users unwilling to pay the toll would still have options. If all roads within a city were controlled by a single private operator (a privatized "road utility", for instance), users would have no choice but to pay whatever the operator charged, or not travel by road. As with other utilities, careful regulation would be needed to ensure the operator's incentive to maximize network efficiency remains.

Whether rate regulation is in fact economically necessary is the subject of debate; for instance Stigler and Friedland (1962) argue there is no difference in prices in the electrical sector due to regulation, because electricity is competitive with other energy sources in the long run. Winston and Yan (2011) also describe some cases in which the gains to society of privatization may be greater without regulation. One expects from experience with other utilities, toll roads, and road concessions in other countries that it would be politically necessary to have some public guarantee of an upper bound on the rates a road utility could charge, as provided by a regulatory agency. The risk is that an upper bound on revenue would be too tight, resulting in financial losses (and one of the causes of municipal takeover), as occurred in the then-private mass transit sector throughout in the United States in the early to mid 20th century.

An alternative to competing routes within the road travel market is a competition for the right to operate all roads within the market. Economic solutions to the monopoly problem include auctions for the privilege for operating routes which would allow the public to recover these monopoly profits, or reverse auctions where firms would bid to charge the lowest rate to operate the route. Future franchising such as Present Value of Revenue (PVR) auctions may entice government agencies to reconsider the toll finance mechanism. The PVR auctions are similar to the so-called Demsetz auctions used in the Build-Operate-Transfer (BOT) approach, with the exception that private firms compete through bidding for the present value of toll revenue they want to obtain from the project. In this way, the consequences of these auctions are: no renegotiations (franchise terms are length- 
ened or shortened to meet bid PVR); no special clauses such as competition (the governments may build additional competing infrastructure projects because of previous consequence); incorporated buyout option (private firms receive their PVR bid, and governments acquire the infrastructure without bargaining behavior); and others. However, disadvantages of PVR auctions include: no incentives to increase demand (if demand increases it shortens the franchise term), and thus projects that require higher service quality may not be appropriate for PVR auctions (Engel et al., 2006).

\section{Roads as a utility}

A model that has been insufficiently explored in the United States is that of public utilities. Many utilities share with transportation systems the characteristic of having a networked structure. Most, if not all, of these utilities are operated on the basis of a payment-for-use system. Utility pricing varies regionally, some locales vary prices by time of day, and users often have the option of choosing different rate plans. These models are never strict marginal cost pricing, but they may improve upon average cost pricing. There are strong parallels between public utilities and transportation services, though some differences exist in the nature of the services consumed, the role of technology, and the structure of institutions and decision making (Hillsman, 1995). A difference of particular relevance to this paper is that investor-owned utilities generally are not exempt from property taxes.

In Great Britain, after World War II public corporations managed most utilities (electricity, gas, water, and rail) while others remained within the public sector (post and telecommunications, roads). The Thatcher administration successfully privatized British Telecom in 1984 and other public utilities in subsequent years, including bus transit and some rail transit, but not roads. The government retained the power to regulate these natural monopoly industries. The 2012 proposal by David Cameron to "privatize" UK roads, by contracting out management of the roads in exchange for a stipend of taxes (but notably not tolling existing roads, only new construction) (Watt, 2012) is interesting, and promises a short-term influx of funds (and possibly better managed roads) in exchange for less revenue downstream.

Hillsman (1995) suggests four categories in which utilities have developed to manage demand:

- Altering infrastructure,

- Packaging services,

- Substituting technologies, and

- Changing the price of service.

Transportation agencies have considered all of these, but implemented them weakly. In reverse order: Prices are largely invariant, technological (modal) substitutions are not viable for most passenger or freight users, bundling and packaging of services is not considered when looking at pricing, and infrastructure is hidebound to engineering standards and difficult to modify. One could easily imagine more creativity on the part of road providers in all of these aspects. The constraints on the application of creativity are due to the engineering culture in a public agency, where risk-taking is discouraged if not punished, and certainly never rewarded.

With some modification, it seems possible to transfer the utility model of governance to road transportation. This model separates the organization delivering the service from the client, is 
subject to rate regulation, and implements a more direct, user-pays system of financing. This model could depoliticize management of the existing transportation system, and would transform but not replace public highway or transportation authorities as the party responsible for providing and maintaining roads.

One example of a transportation system that has transitioned toward a utility-based model is the road authority in New Zealand (Starkie, 1988). This system was designed to be self-financing, with what was originally called the National Roads Board allocating charges among users on the basis of costs incurred. Three types of costs were identified: load costs (related to the thickness of the roadway), capacity costs (related to the width of the roadway), and driver-related costs (covering signing and other costs not related directly to road use). Additional costs that were not included are access costs (related to accessing the network from land and providing a connected network) and environmental costs (relating to system deterioration caused by environmental factors and environmental degradation due to system use). Vehicles are split into two classes on the basis of weight, with vehicles less than 3.5 tonnes paying a charge in the form of a fuel tax.

In the United States, Oregon has a weight-mile tax for heavy trucks. Heavier vehicles pay a distance license fee, which is essentially a form of weight-distance tax. Such a system is relatively straightforward and requires minimal new technology, leading to low collection costs compared with most proposed road pricing systems. Newbery and Santos (1999) have also estimated the costs and relevant charges for a similar, though hypothetical, system of user charges for the UK.

User charging schemes such as these contrast with user charges based on a mileage tax concept utilizing GPS systems (Forkenbrock, 2008). An advantage of a system that can identify location is the ability to charge different rates for different locations (city vs. country, freeway vs. local street, congested vs. uncongested road). GPS-equipped vehicles can log the vehicle location internal to the vehicle without transmitting the information. Some additional communication technology, which might report a reduced form of information (e.g. total amount owed) would be used to complete the transaction. For instance, a pilot study in Oregon (Zhang et al., 2009) used a chip in the vehicle to log distance traveled by zone (an aggregated version of location) and time of day, without storing the precise location. The chip only reported to the external source the total charge owed, calculated by an onboard algorithm. Simpler technologies such as a mileage-based user fee would simply record the odometer reading, but this would not allow differentiation by time of day or location.

While the road user charging concept remains an attractive prospect, its application may still be many years away due to a combination of privacy concerns, implementation and transaction cost issues (Levinson and Odlyzko, 2008), and technological development issues. Some of these concerns might be obviated under a different governance structure, under which neither the legislative nor executive branch of government makes these decisions. Public utilities have a "mean level of trust" of 42 percent, (Jenkins-Smith and Herron, 2004), which is much higher than the trust in the federal government, which hovers in the 20 percent range (Pew Research Center for the People and the Press, 2010). Dynamic pricing, as suggested for toll roads, significantly reduces consumer trust in an organization (Garbarino and Lee, 2003), as prices are no longer predictable and feelings of price gouging take place.

The discussions of road pricing for financing and congestion management in the United States are still largely under the guise of existing institutions doing the pricing. To date, this has essentially been a non-starter. Perhaps with institutional reforms, reconfiguring state and local transportation departments as public utilities rather than government agencies, the logic the public applies to roads 
will change from a perception of one of a public service paid for by the pot of general revenue to a fee-for-service proposition paid for by direct user charges.

\section{Revenue possibilities for sample cities}

This paper aims to determine just how much revenue sample cities would be able to collect in property taxes on streets and roads within their limits. The data sets used in the analysis were obtained from MetroGIS, which compiles regional geographic information for the Twin Cities metropolitan area. Parcel information, major highway routes and land use maps were all used to calculate the area within each city devoted to streets and highways.

Land value was estimated using a procedure developed in a previous project (Junge and Levinson, 2012). The data created in that project included average land values for each census block in the metropolitan area. The methodology was derived from a hedonic pricing model developed by Iacono and Levinson (2009). The model estimated property value as a function of various factors, assigning each factor as adding value to the land or to the improvements to calculate the average land value in each block as a proportion of total property value. The proportion was then applied to the estimated total property value in the parcel data set. Property tax rates were obtained from the respective county assessment offices online.

The land areas covered by roads and rights-of-way were calculated for each city, for all roads and for major highways only. Beginning by importing a layer of census blocks with $100 \%$ coverage of the area into a geographic information system (GIS), other layers were subtracted until only the area of streets and roads remained. The parcel areas were subtracted first. Parcel boundary shapefiles are not consistent across the region; the maps for some counties leave space for road right-of-way, while others show the parcel boundaries as road centerlines. Only the counties in which rights-of-way were reflected in the parcel data (Anoka, Hennepin and Ramsey) could be included in the analysis.

The next subtraction removed areas of open water. Because the parcel and open water shapefiles do not match exactly, some odd, narrow areas remained at the edges of lakes and rivers after this step. Many of these were removed by hand, but enough uncertainty remained in rural areas that the result was not reliable. In response to this issue, townships were removed from the analysis and only incorporated cities in the three counties named above were retained. After subtracting railroad rights-of-way and parks not included in either of the previous subtractions, the remaining areas were considered reasonable estimates of the area in each census block devoted to streets and roads.

The block-level estimates of land value per square meter were then applied to the areas of roads in each block. The resulting values were then summed across each city, and multiplied by the municipal property tax rates. In Minnesota, the stated rates are assessed on the tax capacity of each parcel of land. The formula used to determine tax capacity varies by type of property, and in this case roads are assumed to fall into the category for commercial, industrial and utility establishments. The tax capacity formula for this category was obtained from the Minnesota Department of Revenue online and is shown in Equation 1.

$$
\text { Tax capacity }=1.50 \% * \text { first } \$ 150,000+2.00 \% * \text { remaining value }
$$

In order to apply this formula to the calculation, roads are assumed to comprise one parcel in 
each city. The tax capacity of the road owner/operator in each city was then calculated as $1.50 \%$ of the first $\$ 150,000$ of the value of the land it would own in that city and $2.00 \%$ of the value above $\$ 150,000$. In most of the cities in the analysis, the value of roads and highways far exceeded that amount. Results of the calculations for sample cities are presented in Table 1. The selection allows for a varied mixture of large, central cities and inner and outer suburbs, as well as a wide range of tax rates and proportions of city area covered by roads.

A city evaluating the revenue potential of property taxes on privatized roads would need to consider the effects of pricing on driver behavior and locational and land use decisions, which in turn would affect the land value and profitability of the network as a business. The public would also have an interest in how this arrangement would compare to existing funding sources and free travel. A simulation of marginal-cost pricing for Austin, Texas found that the reduction in vehiclemiles traveled in the city would be minimal, but the reduction in congestion and travel time would create a welfare gain (Gupta et al., 2005). However, the benefit would not be spread evenly across the city, and congested central areas with more captive trips would experience a loss due to higher tolls. To maintain overall economic efficiency, the revenue should be used for public benefit in some way. Reinvestment of the proceeds in transportation is not necessary, and they should not be returned to users based on how much they paid. The Austin simulation concluded that if the receipts were distributed evenly, any welfare losses would become gains for residents in all parts of the city.

Land use effects may be less pronounced and would take longer to appear. Employment and population could be expected to fall in dense central areas and become more evenly dispersed (Gupta et al., 2005). Density in inner-ring suburbs is likely to increase, while the increased cost of travel would lead residents of outer areas to move closer (Eliasson and Mattsson, 2001). Workers would reconsider where they live in relation to their workplaces, but might be more likely to change jobs than residences (Tillema et al., 2010). When travel is underpriced, land value does not rise with decreasing distance from the city center as quickly as it would if travel were priced at marginal cost (Solow, 1973). This can lead to excessive land at the center being devoted to road construction. A private operator taking over the road network might then prefer to convert some current road space to other land uses. The resulting changes in tax capacity and connectivity would affect the ultimate taxable value of the road enterprise and adjacent parcels.

\section{Potential property tax relief}

One option for the extra revenue collected by adding the areas of roads and highways in the city to the property tax rolls would be to reduce the property tax rate for some or all types of property in the city. In fact, this may be the most politically popular use of the funds if they are not needed to cover increased construction or maintenance expenses. This section of the paper describes calculations of the rate reduction possible for residents and businesses if the land value of roads is taxed.

The first step in this procedure was to determine the revenue collected from taxable property in each city. This was accomplished using a GIS and data layers of parcels, land uses and city limits. The land use categories were aggregated into single-family and multi-family residential, commercial and industrial, and institutional groups. Properties that did not fall into a residential or business group, such as churches, schools and parks, were assumed to be exempt from property tax. The parcel data include estimated market values for each property. These were totaled for each 
Table 1: Revenue potential of property taxes on roads and highways by city.

\begin{tabular}{|c|c|c|c|c|c|c|}
\hline City & $\begin{array}{r}\text { Road } \\
\text { area } \\
\left(\mathrm{km}^{2}\right) \\
\end{array}$ & $\begin{array}{r}\text { Highway } \\
\text { area } \\
\left(k m^{2}\right)\end{array}$ & $\begin{array}{r}\text { Land value, } \\
\text { roads } \\
\$ 000\end{array}$ & $\begin{array}{r}\text { Land value, } \\
\text { highways } \\
\$ 000\end{array}$ & $\begin{array}{r}\text { Revenue, } \\
\text { roads } \\
\$ 000\end{array}$ & $\begin{array}{r}\text { Revenue, } \\
\text { highways } \\
\$ 000\end{array}$ \\
\hline Anoka & 2.890 & 0.422 & $\$ 184,101$ & $\$ 12,163$ & $\$ 1,365$ & $\$ 91$ \\
\hline Arden Hills & 3.125 & 1.524 & $\$ 128,759$ & $\$ 44,456$ & $\$ 505$ & $\$ 175$ \\
\hline Bloomington & 15.141 & 3.311 & $\$ 1,175,409$ & $\$ 192,247$ & $\$ 7,734$ & $\$ 1,265$ \\
\hline Brooklyn Center & 4.967 & 1.694 & $\$ 282,885$ & $\$ 58,768$ & $\$ 2,507$ & $\$ 522$ \\
\hline Brooklyn Park & 13.002 & 3.597 & $\$ 622,922$ & $\$ 91,770$ & $\$ 4,393$ & $\$ 648$ \\
\hline Champlin & 3.624 & 0.371 & $\$ 212,714$ & $\$ 12,378$ & $\$ 1,385$ & $\$ 81$ \\
\hline Columbia Heights & 2.198 & 0.191 & $\$ 218,489$ & $\$ 14,957$ & $\$ 1,883$ & $\$ 130$ \\
\hline Coon Rapids & 10.103 & 2.568 & $\$ 579,136$ & $\$ 96,649$ & $\$ 3,560$ & $\$ 595$ \\
\hline Crystal & 3.014 & 0.187 & $\$ 230,603$ & $\$ 5,684$ & $\$ 1,664$ & $\$ 42$ \\
\hline Deephaven & 0.742 & 0.018 & $\$ 63,398$ & $\$ 893$ & $\$ 202$ & $\$ 3$ \\
\hline Eden Prairie & 10.710 & 2.808 & $\$ 650,842$ & $\$ 117,024$ & $\$ 3,627$ & $\$ 653$ \\
\hline Edina & 7.863 & 1.765 & $\$ 893,441$ & $\$ 72,036$ & $\$ 3,780$ & $\$ 305$ \\
\hline Falcon Heights & 0.587 & 0.010 & $\$ 51,418$ & $\$ 0$ & $\$ 191$ & $\$ 0$ \\
\hline Fridley & 5.287 & 1.308 & $\$ 347,352$ & $\$ 79,062$ & $\$ 2,110$ & $\$ 481$ \\
\hline Golden Valley & 5.174 & 1.697 & $\$ 317,300$ & $\$ 58,075$ & $\$ 2,621$ & $\$ 480$ \\
\hline Hilltop & 0.033 & 0.018 & $\$ 2,772$ & $\$ 1,748$ & $\$ 59$ & $\$ 38$ \\
\hline Hopkins & 1.996 & 0.410 & $\$ 167,794$ & $\$ 12,662$ & $\$ 1,540$ & $\$ 117$ \\
\hline Lauderdale & 0.293 & 0.085 & $\$ 23,401$ & $\$ 3,586$ & $\$ 114$ & $\$ 18$ \\
\hline Little Canada & 2.166 & 1.053 & $\$ 69,856$ & $\$ 16,369$ & $\$ 294$ & $\$ 69$ \\
\hline Maple Grove & 11.592 & 2.769 & $\$ 611,351$ & $\$ 73,873$ & $\$ 3,689$ & $\$ 446$ \\
\hline Maplewood & 6.930 & 1.748 & $\$ 332,323$ & $\$ 41,144$ & $\$ 2,048$ & $\$ 254$ \\
\hline Medicine Lake & 0.049 & 0.000 & $\$ 4,675$ & $\$ 0$ & $\$ 29$ & $\$ 0$ \\
\hline Minneapolis & 37.639 & 5.932 & $\$ 5,420,222$ & $\$ 181,874$ & $\$ 61,450$ & $\$ 2,063$ \\
\hline Minnetonka & 11.302 & 3.052 & $\$ 652,486$ & $\$ 138,187$ & $\$ 3,709$ & $\$ 786$ \\
\hline Mounds View & 2.226 & 0.846 & $\$ 89,411$ & $\$ 18,666$ & $\$ 626$ & $\$ 131$ \\
\hline New Brighton & 3.282 & 0.843 & $\$ 210,793$ & $\$ 33,112$ & $\$ 1,383$ & $\$ 218$ \\
\hline New Hope & 2.396 & 0.292 & $\$ 180,975$ & $\$ 14,983$ & $\$ 1,525$ & $\$ 127$ \\
\hline North St. Paul & 1.739 & 0.163 & $\$ 122,161$ & $\$ 4,732$ & $\$ 527$ & $\$ 21$ \\
\hline Osseo & 0.576 & 0.201 & $\$ 36,067$ & $\$ 4,607$ & $\$ 261$ & $\$ 34$ \\
\hline Plymouth & 12.706 & 2.785 & $\$ 802,441$ & $\$ 143,316$ & $\$ 3,737$ & $\$ 668$ \\
\hline Richfield & 4.772 & 0.933 & $\$ 420,849$ & $\$ 32,829$ & $\$ 3,013$ & $\$ 236$ \\
\hline Robbinsdale & 2.072 & 0.504 & $\$ 164,151$ & $\$ 10,171$ & $\$ 1,185$ & $\$ 74$ \\
\hline Roseville & 6.785 & 1.957 & $\$ 435,975$ & $\$ 97,983$ & $\$ 2,039$ & $\$ 459$ \\
\hline Shoreview & 3.903 & 0.544 & $\$ 231,757$ & $\$ 10,089$ & $\$ 1,091$ & $\$ 48$ \\
\hline Spring Lake Park & 1.407 & 0.413 & $\$ 80,375$ & $\$ 14,164$ & $\$ 764$ & $\$ 135$ \\
\hline St. Anthony & 1.029 & 0.008 & $\$ 86,230$ & $\$ 0$ & $\$ 788$ & $\$ 0$ \\
\hline St. Louis Park & 5.981 & 1.417 & $\$ 617,262$ & $\$ 93,508$ & $\$ 4,289$ & $\$ 650$ \\
\hline St. Paul & 31.920 & 5.341 & $\$ 3,464,988$ & $\$ 165,268$ & $\$ 21,065$ & $\$ 1,005$ \\
\hline Vadnais Heights & 2.883 & 1.187 & $\$ 120,564$ & $\$ 27,029$ & $\$ 438$ & $\$ 99$ \\
\hline Wayzata & 1.585 & 0.573 & $\$ 108,875$ & $\$ 23,975$ & $\$ 444$ & $\$ 98$ \\
\hline Woodland & 0.104 & 0.000 & $\$ 8,675$ & $\$ 0$ & $\$ 13$ & $\$ 0$ \\
\hline
\end{tabular}


land use in each city.

The tax capacity formula for commercial property shown above was used once more, and the formula for residential property is given by Equations 2 and 3. The calculation shown for multifamily housing is used for properties with four or more units. This is assumed here to apply across the board for all properties within multi-unit land use zones. Total current revenue was calculated by applying the tax rate to the total tax capacity in each city. To determine the reduction possible with the addition of tax on roads and highways, their tax capacity was added to the totals, and the revenue total was divided by the result.

$$
\begin{gathered}
\text { Tax capacity }_{S F}=1.00 \% * \text { first } \$ 500,000+1.25 \% * \text { remaining value } \\
\text { Tax capacity }{ }_{M F}=1.25 \% * \text { total value }
\end{gathered}
$$

The results of the calculations are shown in Figures 1 and 2. It can be seen that although the revenue potential of taxing roads is considerable, in most cities it would still represent a small proportion of tax capacity. Factors that would influence the potential for property tax rate reduction include the value of land and buildings in the city, the amount of developed versus undeveloped land, and the proportion of the land area reserved for roads. Cities with high land values and lower structure values would be able to reduce property tax further than those whose land values are lower and would not be supplemented as much by adding roads and highways. Sparsely developed cities with a few structures separated by undeveloped and untaxable land might see a greater potential for tax relief, since more roads are needed in relation to the existing tax base. The cities that would be able to reduce property tax rates the most by taxing roads are those where roads take up a higher percentage of the land area and where structure values are relatively low.

\section{Contribution to Scholarly Knowledge}

The results show that many of the cities in Hennepin County would be able to increase property tax revenue substantially if roads within the city limits were privatized and made taxable. Even if only major highways were included, which might be a more likely scenario, several cities along those corridors could increase annual property tax revenue by six-figure sums. Privatizing all local roads would also remove maintenance costs from city budgets, enabling funds to be directed toward the provision of other services or providing property tax relief. The negotiation would be more complicated for major routes, since maintenance is usually administrated by other agencies such as the state department of transportation.

This analysis does not attempt to estimate the user fees that would be charged by a private road operator. Calculating the appropriate toll level and the resulting effects on resident and road user welfare compared to the property tax status quo is left to future research. Private operation could result in improved efficiency, and extending the privatization to ownership would create another opportunity for improved efficiency in land allocation. Benefits of this nature would need to be weighed against the costs of toll or user fee collection and the equity implications of changing the funding structure. This analysis simply attempts to determine the potential effect on municipal government revenue of road privatization. Future analysis could also determine the land value of on-street parking or the property tax effects of highway expansion. 


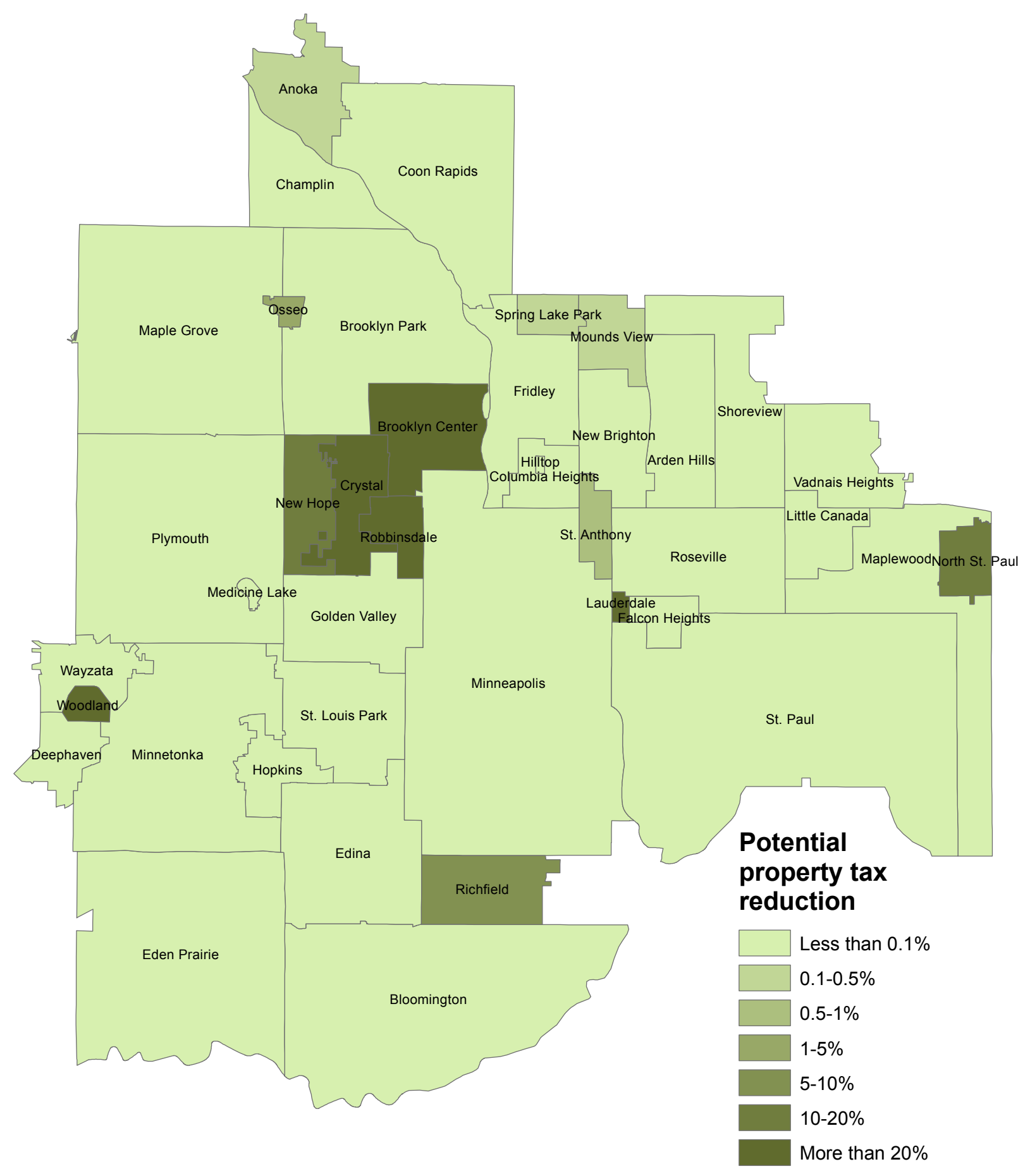

Figure 1: Potential for property tax reduction if all local roads were assessed property tax. 


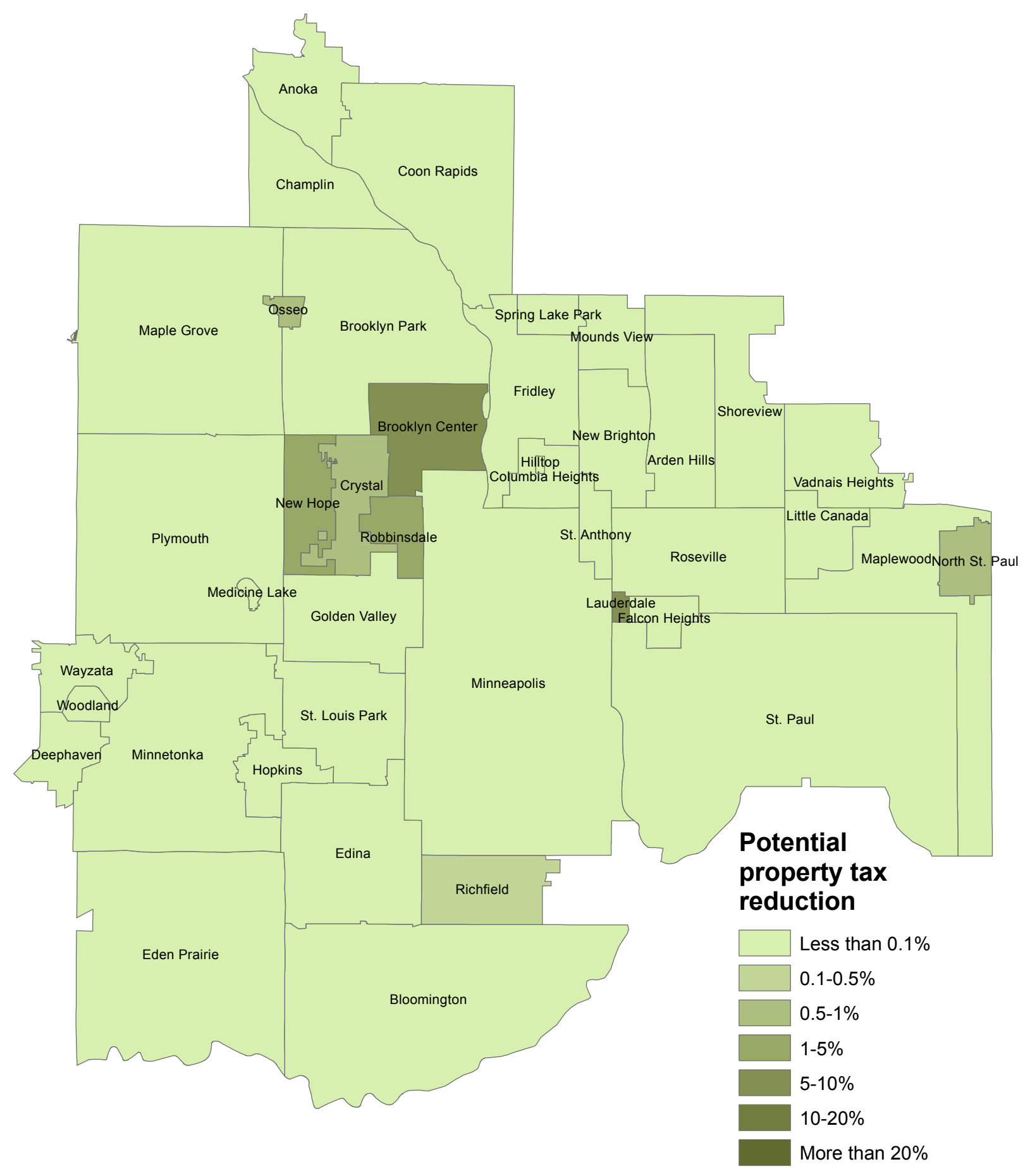

Figure 2: Potential for property tax reduction if major highways were assessed property tax. 
The estimates for road value may be high, since the land value estimates used derive some increment from accessibility provided by the roads they abut, and removing this connectivity by converting road-covered land to some other use would have the effect of reducing land values citywide. However, roads also have some structural value owing to the materials of which they are made, and service value created by the demand for activities made possible by transportation. Moreover, assuming that tolls are set such that private road operation is profitable, the business would have value representing the future revenue stream. When all of these factors are taken into account, it may be more likely that the taxable property values of the road enterprises in this analysis are in fact underestimated. 


\section{References}

Albalate, D., G. Bel, and X. Fageda (2009). Privatization and regulatory reform of toll motorways in europe. Governance 22(2), 295-318.

Daniels, R. and M. Trebilcock (1996). Private provision of public infrastructure: An organizational analysis of the next privatization frontier. University of Toronto Law Journal 46(3), 375-426.

Eliasson, J. and L.-G. Mattsson (2001). Transport and location effects of road pricing: A simulation approach. Journal of Transport Economics and Policy 35(3), 417-456.

Engel, E., R. Fischer, and A. Galetovic (2002). A new approach to private roads. Regulation Fall, $18-22$.

Engel, E., R. Fischer, and A. Galetovic (2006). Privatizing highways in the united states. Review of Industrial Organization 29(1), 27-53.

Fields, G., D. Hartgen, A. Moore, and R. Poole (2009). Relieving congestion by adding road capacity and tolling. International Journal of Sustainable Transportation 3(5), 360-372.

Forkenbrock, D. (2008). Policy Options for Varying Mileage-Based Road User Charges. Transportation Research Record: Journal of the Transportation Research Board 2079(-1), 29-36.

Friedman, M. and D. J. Boorstin (1996). How to plan and pay for the safe and adequate highways we need. In Roads in a Market Economy, pp. 223-245. Avebury Technical.

Garbarino, E. and O. Lee (2003). Dynamic pricing in internet retail: effects on consumer trust. Psychology and Marketing 20(6), 495-513.

Gómez-Ibáñez, J. A., J. R. Meyer, and D. E. Luberoff (1991). The prospects for privatising infrastructure: Lessons from us roads and solid waste. Journal of Transport Economics and Policy 25(3), 259-278.

Gupta, S., S. Kalmanje, and K. M. Kockelman (2005). Road pricing simulations: Traffic, land use and welfare impacts for Austin, Texas. Presented at the Transportation Research Board 84th Annual Meeting, January 9-13.

Hillsman, E. (1995). Transportation DSM: building on electric utility experience. Utilities Policy 5(3-4), 237-249.

Iacono, M. and D. Levinson (2009, June). The economic impact of upgrading roads. Technical Report MN/RC 2009-16, Minnesota Department of Transportation Research Services Section.

Jenkins-Smith, H. and K. Herron (2004). A Decade of Trends in Public Views on Security: U.S. National Security Surveys 1993-2003.

Junge, J. and D. Levinson (2012). Financing transportation with land value taxes: Effects on development intensity. Journal of Transport and Land Use 5(1), 49-63.

Levinson, D. (2002). Financing transportation networks. Edward Elgar. 
Levinson, D. and A. Odlyzko (2008). Too expensive to meter: The influence of transaction costs in transportation and communication. Philosophical Transactions of the Royal Society A: Mathematical, Physical and Engineering Sciences 366(1872), 2033.

Newbery, D. and G. Santos (1999). Road taxes, road user charges and earmarking. Fiscal Studies 20(2), 103-132.

Pew Research Center for the People and the Press (2010). Public Trust in Government: 1958-2010.

Poole, R. (1997). Privatization: A new transportation paradigm. Annals of the American Academy of Political and Social Science 553, 94-105.

Poole, R., C. Orski, and R. P. P. Institute (1999). HOT networks: A new plan for congestion relief and better transit. Reason Public Policy Institute.

Poole, R. and P. Samuel (2006). The return of private toll roads. Public roads 69(5), 38.

Poole, R. and Y. Sugimoto (1995). Congestion relief toll tunnels. Transportation 22(4), 327-351.

Poole Jr, R. and P. Fixler Jr (1987). Privatization of public-sector services in practice: Experience and potential. Journal of Policy Analysis and Management 6(4), 612-625.

Roth, G. (1996). Roads in a Market Economy. Avebury Technical.

Samuel, P. and R. Poole (2005). Should States Sell Their Toll Roads? Reason Public Policy Institute.

Samuel, P., R. Poole, and J. Holguin-Veras (2002). Toll truckways: A new path toward safer and more efficient freight transportation. Reason Public Policy Institute.

Solow, R. M. (1973). Congestion cost and the use of land for streets. The Bell Journal of Economics and Management Science 4(2), 602-618.

Staley, S. and A. Moore (2009). Mobility First: A new vision for transportation in a globally competitive twenty-first century. Rowman \& Littlefield Pub Inc.

Starkie, D. (1988). The New Zealand road charging system. Journal of Transport Economics and Policy 22(2), 239-245.

Stigler, G. and C. Friedland (1962). What can regulators regulate-the case of electricity. Journal of Law and Econics 5, 1.

Tillema, T., B. van Wee, and D. Ettema (Published online May 25, 2010). Road pricing and relocation decisions of dutch households. Urban Studies.

Tsai, J.-F. and C.-P. Chu (2003). The analysis of regulation on private highway investment under a build-operate-transfer scheme. Transportation 30, 221-243.

Viton, P. A. (1995). Private roads. Journal of Urban Economics 37, 260-289. 
Watt, N. (2012). David Cameron unveils plan to sell off the roads: Sovereign wealth funds to be allowed to lease motorways in England, says prime minister. The Guardian Newspaper Sunday 18 March 2012.

Winston, C. and J. Yan (2011). Can privatization of U.S. highways improve motorists' welfare? Journal of Public Economics 95, 993-1005.

Yang, H. and Q. Meng (2000). Highway pricing and capacity choice in a road network under a build-operate-transfer scheme. Transportation Research Part A 34, 207-222.

Zhang, L., B. McMullen, D. Valluri, and K. Nakahara (2009). Vehicle mileage fee on income and spatial equity. Transportation Research Record: Journal of the Transportation Research Board 2115(-1), 110-118. 